\title{
Retention and Satisfaction of Novice Teachers: Lessons from a School Reform Model
}

\author{
Elizabeth J. Glennie ${ }^{1}$, Marcinda Mason ${ }^{1}$, Julie A. Edmunds ${ }^{2}$ \\ ${ }^{1}$ RTI International, 3040 East Cornwallis Road, Research Triangle Park, NC, 27709-2194, USA, Phone: 919-541-6434 \\ ${ }^{2}$ SERVE Center at University of North Carolina at Greensboro, 2634 Durham-Chapel Hill Boulevard, Suite 208, \\ Durham, NC, 27707, USA, Phone: 336-574-8727 \\ Correspondence: Elizabeth J. Glennie, RTI International, 3040 East Cornwallis Road, Research Triangle Park, NC, \\ 27709-2194, USA. Phone: 919-541-6434.
}

Received: December 31, 2015 Accepted: January 21, 2016 Online Published: March 14, 2016

doi:10.11114/jets.v4i4.1458

URL: http://dx.doi.org/10.11114/jets.v4i4.1458

\begin{abstract}
In many countries, novice teachers, or those with fewer than four years of experience, have a higher turnover rate than do more experienced teachers. Using teacher employment data, we examine whether schools in an American whole-school reform model are better able to retain novice teachers. Using survey data, we investigate whether novice teachers in a particular school reform model are more satisfied with school leadership than their peers in traditional high schools. In this reform model, early college high schools, high schools are located on college campuses and students have the opportunity to earn an associate's degree or two years of credit in the state university system. This model emphasizes a shared mission and shared leadership. We find that early colleges had a higher turnover rate than their neighbor schools, and a higher percentage of early college teachers were novices. However, these novice teachers were not more likely to leave than novice teachers in traditional schools were. Early college novice teachers received more personalized support and were more satisfied with school leadership than their peers in traditional high schools. Under certain conditions, schools can have higher retention rates for novice teachers.
\end{abstract}

Keywords: novice teachers, teacher job satisfaction, teacher turnover, school reform

\section{Introduction}

In the United States, policymakers and practitioners have begun to develop a set of innovative high school reform models in response to concerns about low high school graduation rates and economic competitiveness (Cullen, Levitt, Robertson \& Sadoff, 2013; Edmunds \& McColskey, 2007; Hanushek, Peterson \& Woessman, 2013). In addition to changing the high school experience for students, these reform models often aim to create a different environment for teachers, with a shared mission and leadership. Innovative school settings often have higher percentages of novice teachers, and across all schools, novice teachers are more likely to leave their jobs, particularly if they do not have peer assistance or administrative support (Curtis, 2012; Barnes, Crowe, \& Shaeffer, 2007). It is particularly important to pay attention to their experiences. As a case study for examining teacher characteristics and teacher perceptions of working conditions in an innovative high school setting, this article uses the early college high school model (hereafter referred to as early colleges), in which small schools blend the high school and college experiences. We focus specifically on the experiences of novice teachers.

Using individual teacher licensure/salary data, we examine whether the schools in this reform model are better able to retain qualified teachers than traditional schools in their districts, and whether novice teachers are more likely to stay in these reform model schools. Then, using teacher survey data, we examine whether the new early college teachers are more satisfied with their working conditions than their peers. Questions about working conditions focus on satisfaction with instructional support, leaders' responsiveness to various teacher concerns, and teachers' leadership roles. The lessons learned from examining teachers in this specific school reform model may help to inform strategies for retaining teachers in other types of schools.

\subsection{Retaining Qualified Teachers}

Schools face challenges in retaining qualified teachers, some of which have to do with a school's culture Allensworth, 
Ponisciak, \& Mazzeo, 2009; Boyd, et al., 2011; Curtis, 2012; Jo, 2014; Johnson, Kraft, \& Papay, 2012). A school's location, student body poverty level, and levels of student achievement affect the likelihood that it will retain qualified teachers (Allen, 2005; American Association of State Colleges and Universities, 2005; Barnes, Crowe \& Schaeffer, 2007; Newton, Rivero, Fuller, \& Dauter, 2011). Schools cannot control these factors, but they can control other elements that influence teacher satisfaction and turnover. Many teachers leave their jobs because of dissatisfaction with aspects of the school's culture, lack of administrative support, limited influence on school policies, large teaching loads, and limited opportunities for professional development (Allensworth, Ponisciak, \& Mazzeo, 2009; Boyd, et al., 2011; Curtis, 2012). The relational aspects of teachers' working conditions have a strong influence on their job satisfaction and intention to remain at the school (Jo, 2014; Johnson, Kraft, \& Papay, 2012). Teachers tend to report greater job satisfaction and the intention to remain in their schools when they have positive feelings about the school's leadership and their relationships with colleagues. Turnover rates are lower in schools where teachers report better principal leadership, more autonomy within the classroom, and richer opportunities for professional development (Ingersoll \& May, 2012). Where teachers report higher levels of participation in school decision-making, turnover is also lower (Liu, 2007). These relationships hold net of the schools' student demographic characteristics. Even in high-poverty schools, which often face challenges attracting and retaining qualified teachers, teachers leave due to elements of the working conditions pertaining to school leadership and collegial relationships (Simon \& Johnson, 2015). In New York City, teachers who hold less positive views of their administrators are more likely to transfer or leave teaching entirely than those who hold more positive views, net of structural factors such as facilities and safety (Boyd et al., 2011). In North Carolina, the higher the perceived quality of school leadership, the less likely teachers are to leave or plan to leave the school (Ladd, 2011).

Some teachers leave their jobs to retire or to leave teaching altogether, but many look for better teaching jobs (Ingersoll \& May, 2012; Gray \& Taie, 2015; Keigher, 2010). Even when teachers move to a new school, the schools that lose teachers face disruptions and have to expend resources to hire and train new teachers. In addition, the departure of teachers may temporarily add to the workload of teachers who remain. Teacher turnover can harm students as well. The cost of recruiting new teachers can be substantial, and turnover undermines at-risk schools (Barnes, Crowe \& Schaefer, 2007). A study of New York schools found that students in schools experiencing high rates of teacher turnover have lower achievement than those in schools with low teacher turnover rates, net of other student, classroom, and school characteristics (Ronfeldt, Loeb, \& Wyckoff, 2013).

High turnover rates can disrupt the development of organizational capital — a social resource that facilitates cooperation and communication within an organization, such as a school. Organizational capital has structural, relational, and cognitive dimensions. The structural dimension refers to the structure of the ties between actors, whereas the relational dimension refers to the personal relationships, a shared sense of obligation, and trust. The cognitive dimension refers to a shared understanding of systems (Nahapiet \& Ghoshal, 1998). High instability through teacher turnover does not affect the structure of the ties between actors, but it harms the relational and cognitive aspects of organizational capital. When teachers have to be replaced, it takes time for new hires to develop trusting relationships and a shared understanding of systemic requirements and strategies for meeting organizational goals.

Low organizational functioning and turnover influence each other. Teachers are more likely to leave schools that have low organizational function, and in schools with high turnover and low stability, leaders have difficulty enforcing organizational norms and establishing organizational functioning (Holme \& Rangel, 2012). This lack of stability may make it more difficult to implement innovative school reforms because it takes time for teachers to understand the mission of a new program and the instructional practices best suited for it (Berends, Bodilly, \& Kirby, 2002; Desimione, 2002).

Many novice teachers leave the profession before their skills are honed through experience. In the United States, within 5 years of beginning teaching, about 20 percent of new teachers left teaching altogether, and another 10 percent changed schools. Providing support to novice teachers can influence their decisions to stay in their jobs (Ingersoll, 2012). A higher percentage of new teachers who were assigned a mentor remained in teaching 5 years later compared to new teachers who did not have a mentor in the same content area (Gray \& Taie, 2015). Teachers who received supports - including having a mentor in the same field, having common planning time, and having scheduled collaboration with other teachers - were less likely to depart after their first year (Ingersoll, 2012; Harris, 2015). Novice teachers who shared organizational preferences for practices with their colleagues and who are committed to the goals of the school were more likely to say they intend to remain teaching in their school (Pogodzinski, Youngs, \& Frank, 2013). 


\subsection{Teacher Turnover in Innovative School Settings}

In newly created schools, even experienced staff are new to the school. Most teachers do not immediately understand the shared vision, or trust their colleagues. Value consonance, or teachers' perceptions that their values are in congruence with those of the school, is associated with feelings of belonging to the school and job satisfaction (Skaalvik \& Skaalvik, 2011). Because it takes time to build a shared vision and to develop feelings of value consonance, a whole school reform model may take several years to implement fully (Berends, 2000). If high teacher turnover diminishes organizational capacity, innovative schools face implementation challenges. These innovative settings can also exacerbate or mitigate teacher turnover. Teacher turnover could be exacerbated in small-sized schools if those schools place increased demands on teachers (Kahne, Sporte, de la Torre, \& Easton, 2006). In contrast, teacher turnover could be lower in innovative schools that create more positive working conditions. Teachers who perceive top-down decision-making may resist the effort, compared with those who believe they have a shared vision and are part of the decision-making process (Berends et al., 2002). Successful implementation depends on leadership with strong communication skills and strong support of teachers (Desimione, 2002). If school reform models promote better leadership and shared decision-making, and if teachers feel supported, these reforms may influence teachers' perceptions of their working conditions and decisions to stay in their jobs.

\subsection{The Early College High School Reform Model}

Implementers of innovative school models seek to change the school's climate to enhance student learning and engagement. These changes may also affect teachers' satisfaction with the school. The early college high school, the focus of this article, is an American school choice model in which publicly funded schools operate with distinct organizational strategies and curricular priorities. The biggest difference between early colleges and traditional high schools is that early colleges are located on 2- or 4-year college campuses, and students are expected to take college classes while in high school. Early colleges are newly established schools rather than existing schools that were transformed.

In early colleges, students apply to attend and teachers have greater decision-making roles. In these schools, teachers are expected to share a certain mission. Early colleges focus on better preparing students for college and career, creating a seamless curriculum between high school and college, and giving students work-based learning experiences. The structure of this model may influence teachers as well as students.

Although early colleges are located across the United States, this paper focuses the early college model in North Carolina. Here, each early college is expected to adopt the following specific goals and implement specific practices developed by the North Carolina New Schools (NCNS) agency (North Carolina New Schools, 2013): (1) ensuring that all students are ready for college, (2) instilling powerful teaching and learning in schools, (3) redefining professionalism, (4) fostering shared leadership, (5) personalizing educational resources, and (6) implementing a purposeful design. Some of these principles may make it easier for early colleges to attract and retain highly qualified teachers and foster an environment that increases teachers' job satisfaction. Redefining professionalism means that staff members have a collaborative work orientation and shared responsibility for decision making, and schools have a commitment to improving the capacity of staff. Fostering shared leadership means that staff in NCNS schools work to develop a shared mission for their school and work actively as agents of change, sharing leadership for improved student outcomes. Implementing a purposeful design means that time, space, and other resources are allocated to ensure that best practices become commonplace. These principles focus on the way teachers and leaders interact, which has been shown to influence teacher turnover (Pogodzinski et al., 2013; Smith \& Ingersoll, 2004).

Recent research has shown a statistically significant positive impact of the early college high school model on its students in North Carolina (Edmunds, J., Bernstein, L., Glennie, E., Wilse, J, Arshavsky, N., Unlu, F., \& Dallas,A., 2010; Kaniuka \& Vickers, 2010) and in 10 early colleges in five states, including North Carolina (Berger et al., 2013). A study in which students were randomly accepted into the state's early colleges found that students in these schools were statistically significantly more likely to take and pass college preparatory classes, compared with students in a randomly formed control group. Additionally, early college students had statistically significantly higher attendance and lower suspension rates than their peers attending traditional high schools (Edmunds, J., Bernstein, L., Glennie, E., Wilse, J., Arshavsky, N., Unlu, F., \& Dallas,A., 2010). Few evaluators, however, have examined the way the early college model might influence teachers.

\subsection{Hypotheses}

Our analyses addressed the hypotheses:

(1) Early college teachers are more experienced, more qualified, and more likely to remain in their jobs than their peers in traditional high schools. 
(2) Novice teachers in early college high schools are less likely to leave their jobs than those in traditional schools.

(3) Novice teachers in early college high schools are more satisfied with their working conditions than their peers in traditional high schools.

The first hypothesis compares the characteristics of all teachers in early colleges to those in traditional schools. The second hypothesis examines differences in turnover rates for novice teachers in early colleges and traditional schools, and the third hypothesis examines differences in job satisfaction of novice early college teachers and novices in traditional schools.

\section{Method}

This analysis used a mixed methods approach with multiple data sources to address these hypotheses. Within the field of evaluation, using multiple methods of inquiry can enhance understanding of phenomena (Johnson, Onwuegbuzie, \& Turner, 2007). Many research organizations, such as National Institutes of Health, National Science Foundation, and Robert Wood Johnson Foundation, promote mixed methods research in their technical guidelines (Creswell \& Plano Clark, 2011). Our study utilized a sequential explanatory design with the primary emphasis on the quantitative data and the qualitative data helping explain the quantitative findings (Creswell, Plano Clark, Gutmann, \& Hanson, 2003). We used quantitative data, such as teacher licensure and employment data, to look at qualifications and turnover. We also used a state-administered survey to address questions about teacher satisfaction.

To examine the effect of the early college high school model on teachers, we used individual teacher licensure and employment data collected by the North Carolina Department of Public Instruction (NCDPI). We used these data to compare the qualifications of early college teachers to those of teachers in traditional schools within their districts and to examine whether early colleges are better able to retain novice teachers. To understand teachers' perceptions of their schools, we used data from North Carolina's Teacher Working Conditions Survey, which is conducted every other year by NCDPI. We used survey data to examine whether early college teachers report being more satisfied with their working environment than their peers in traditional schools. In particular, we focused on teachers' perceptions of school leaders in terms of leaders' support of various concerns and shared leadership. Analyses focused on novice teachers, defined as those with fewer than 4 years of experience.

\subsection{Identifying Teachers in Early Colleges and Comparison Schools}

We used data from the 2009-2010 National Center for Education Statistics (NCES) Common Core of Data, a national dataset, to identify active high schools in North Carolina; i.e., those that enrolled students in the 9th- through 12th-grade levels in that year. To determine whether a school was an early college, we obtained the list of early colleges from staff at NCNS.

Analyses of teacher qualifications and turnover were based on 2009-2010 and 2010-2011 Licensure-Salary Pay Snapshots data collected by NCDPI and obtained from the North Carolina Education Research Data Center at Duke University. The Licensure-Salary Pay Snapshots data file includes records for school personnel in certified positions (i.e., teachers, counselors, and principals) and provides information about their education level, years of experience, and type of teaching license. Here, novice teachers are those with fewer than 4 years of teaching experience, whether or not they are fully licensed. Teachers who are not fully licensed are those who have an emergency, provisional, or temporary license, regardless of their years of experience. Fully licensed teachers are those who have met all requirements set by the State Board of Education, and who have a clear initial license (for new teachers) or clear continuing license (for those with at least four years of experience). Because some teachers are licensed in multiple areas, we retained the license with the most deficiencies to be satisfied before becoming an initial or continuing license; that is, someone who is not fully licensed in any area would not count as being fully licensed. This method for categorizing licenses is the same approach that NCDPI uses to produce the North Carolina School Report Cards (North Carolina Department of Public Instruction, 2010), which provide annual summary information about individual schools.

Using 2 years of these pay snapshots, we identified those who stayed teaching in the same school from one year to the next (stayers) and those who left their jobs after spring 2010 (leavers). Leavers include those who transferred to schools within the same district, those who went to another district, and those who left teaching in North Carolina public schools altogether. To limit the data to high school teachers, we matched the 2009-2010 Licensure-Salary Pay Snapshots to the school data file described above and kept records for those teaching in high schools. Following NCDPI guidelines for identifying classroom teachers, we excluded records for personnel in the other certified positions (e.g., counselor, principal). The 2009-2010 single teacher record file included 30,413 teachers, each of whom taught in up to five schools. For the 2010-2011 data, we included all certified positions to identify those who had transferred into a nonteaching position. We matched all teachers from 2009-2010 to all certified personnel in high schools in 2010-2011. For those records that matched, we determined whether the teacher was at the same school in both years (i.e., a stayer). 
If teachers worked in more than one school in either year, we identified stayers as those who taught in at least one school that was the same in both years. With this approach, teacher turnover numbers include those who left a teaching position from one year to the next, whether to leave the North Carolina public school system entirely, to teach in a different school, or to take a nonteaching job within the school system.

Because the early college high school initiative began in 2004, early colleges are relatively new and, as noted above, newly established schools face challenges in building trust and relationships and fostering a shared sense of mission. Further, new schools may have less-qualified teachers to the extent that they are unable to attract teachers from existing schools and must rely on newly certified teachers. To examine the relationship between the length of time that early colleges had been in operation (i.e., the number of years) and teacher turnover and qualifications, we used 2005-2006 through 2009-2010 information from the NCES Common Core of Data Public School Universe and the North Carolina School Report Card files. These data files contain information on school characteristics, school academic profile, student characteristics, teacher qualifications, and school safety.

We obtained information on the opening date of early colleges from the Educational Directory and Demographical Information Exchange (EDDIE) maintained by NCDPI. EDDIE is an online application containing local education agency and school information (such as school types, grade levels, and program types). Using information on the schools' initial year of operation, we calculated the average turnover rate of teachers, the percentage of teachers who were fully licensed, and the percentage of novice teachers for the first through seventh years of operation. For schools that opened in 2006, we used 2006 data to identify teacher qualifications for the first year of operation, 2007 data to capture teacher qualifications in their second year of operation, and so forth. Then, for schools opening in 2007, we used 2007 data to identify the teacher qualifications for their first year, 2008 data for their second year, and so forth. In the few cases in which schools had missing turnover information for a given year, the school was not included in the average rate for that year.

\subsection{Measures of Teacher Job Satisfaction}

The examination of teacher job satisfaction relied on the North Carolina Teacher Working Conditions Survey, an online anonymous survey of all North Carolina public educators that asks teachers about their perceptions of their school environment. The survey is funded by the North Carolina General Assembly and led collaboratively by the Governor, the State Board of Education, and the North Carolina Teacher Working Conditions Advisory Committee. This survey is conducted every other year in the spring. In 2010 it had an 89\% response rate (North Carolina Professional Teaching Standards Commission, 2010). The 2010 Teacher Working Conditions Survey data file included 105,688 records; limiting the data to include only classroom teachers left 91,490 records.

Because the survey field that identifies the respondent's position does not distinguish between classroom teachers and other types of teachers, the survey data include more records than the Licensure-Salary Pay Snapshots do. The Teacher Working Conditions Survey data are anonymous and cannot be linked to the Licensure-Salary data sources. However, their measure of years of experience permits limiting the sample to novice teachers.

Most of the questions on the Teachers Working Conditions Survey have a 4-point Likert scale: strongly disagree, disagree, agree, strongly agree. We examined those who strongly agreed with each statement for early college novice teachers, compared with novice teachers in traditional schools. Questions about types of supports new teachers received were coded as yes or no for each type of support.

Given that past research, as noted above, has found that teachers report greater satisfaction and intention to remain in their jobs when they have positive feelings about school leadership, we focused on specific questions related to teachers' perceptions of leadership support. These questions included perceptions of instructional support, leaders' responsiveness to teachers' concerns about various items, and shared leadership. After identifying items that seemed related to each of these working conditions, we conducted exploratory factor analysis using the common extraction method of principal components analysis to examine the associations among the items, and only kept items with unrotated factor loadings above .75. All of the questions had possible responses of strongly agree, agree, disagree, and strongly disagree. We compared the percentage of strongly agree responses given by early college teachers to the percentage of strongly agree responses given by teachers in traditional schools in the same district.

\subsection{Making Comparisons}

Comparison schools (i.e., neighbor schools) included traditional schools that serve students in grades 9 through 12 and were located in districts with early colleges. Although early colleges employ a nontraditional school model, they are nested in the same districts as traditional schools. Consequently, in our analyses of qualifications, we assumed that the hiring pool for the early colleges would be the same as, or very similar to, that of the other high schools within the district. Further, we expected that because early colleges were in the same locale with the same district policies as their 
neighbor schools, the early college teachers would face working conditions and employment options that were more similar to those in their neighbor schools than to those of teachers outside of their district. Consequently, all comparisons examined differences between early college teachers and their neighbor teachers.

Using the Wilcoxon Mann-Whitney test, we determined whether the differences in qualifications, turnover, and job satisfaction between the early college teachers and neighbor teachers were statistically significant. The Wilcoxon test is valid for distributions that are not normal and is less sensitive to outliers than a two-sample $t$-test (Bellera, Julien \& Hanley, 2010).

As part of a broader study looking at the implementation and impact of early colleges, we conducted site visits to 18 early colleges. For this analysis, we used data from interviews with principals at each of these 18 schools. The interviews included questions about the goals of the early college and professionalism and included questions pertaining to collaboration and professional development. The interviews were transcribed and data entered into Atlas.ti software for coding. The data were then coded for themes independently by two researchers who met to reconcile the codes as needed.

\section{Results}

\subsection{Teacher Qualifications and Turnover}

The first hypothesis examines whether early college teachers $(n=626)$ are more experienced, more qualified, and have lower turnover rates than neighbor teachers in traditional high schools $(n=20,089)$. Overall, the results suggest that early college teachers are more qualified based on educational level, but are newer to the profession and are more likely to leave their jobs. Table 1 presents these comparisons. In 2010, compared with neighbor teachers, early college teachers were less experienced overall but more highly educated. Early college teachers were more likely to be novice teachers $(23 \%$ vs. $16 \%)$ and were less likely to have 11 or more years of experience $(45 \%$ vs. $55 \%)$. There was no statistically significant difference between early college teachers and their peers in terms of having 4 to 10 years of experience. Concerning educational level, early college teachers were more likely to have postgraduate education than neighbor teachers ( $41 \%$ vs. $34 \%)$, and this difference was statistically significant.

The percentage of early college teachers who were not fully licensed did not differ significantly from that of neighbor teachers (6\% vs. $7 \%$ ). Fully licensed teachers possess either an initial license or a continuing license. Those who are new to the profession are issued an initial license, which is valid for 3 years, that allows them to begin teaching on an independent basis. Continuing licenses are intended for teachers who have 3 or more years of teaching experience and are valid for 5 years. ${ }^{1}$ Because early college teachers are more likely to be novice teachers, we expected that they would be more likely to have an initial license, and they were. As shown in Table 1, 17\% of early college teachers had an initial license, compared with $11 \%$ of neighbor teachers. Further, $77 \%$ of early college teachers had a continuing license, compared with $83 \%$ of neighbor teachers.

Concerning the turnover rate, early college teachers were more likely than neighbor teachers to leave their schools $(20 \%$ vs. 17\%). However, examining turnover rates by years of experience showed no statistical difference between early college and neighbor novice teachers or between early college and neighbor teachers with 4 to 10 years of experience. The turnover rate for early college teachers with more than 10 years of experience was higher than that for neighbor teachers $(20 \%$ vs. $15 \%)$.

\footnotetext{
${ }^{1}$ Information on North Carolina professional educator's licenses retrieved from http://www.ncpublicschools.org/licensure (accessed February 2016).
} 
Table 1. Average qualifications of North Carolina early college high school (ECHS) and traditional teachers in Early College districts.

\begin{tabular}{|c|c|c|c|}
\hline & $\underset{\%}{\text { ECHS teachers }}(\mathrm{N}=626)$ & $\begin{array}{c}\text { Traditional neighbor teachers }(\mathrm{N}=20,089) \\
\%\end{array}$ & Difference \\
\hline \multicolumn{4}{|l|}{ Education level } \\
\hline Bachelor's & 58.7 & 66.5 & $-7.8 * * *$ \\
\hline Master's & 41.3 & 33.5 & $7.8^{* * *}$ \\
\hline \multicolumn{4}{|l|}{ Years of experience } \\
\hline 0 to 3 years (Novice) & 23.3 & 16.3 & $7.0 * * *$ \\
\hline 4 to 10 years & 31.3 & 28.6 & 2.7 \\
\hline 11 or more years & 45.3 & 55.1 & $-9.8 * * *$ \\
\hline \multicolumn{4}{|l|}{ Licensure status } \\
\hline Not fully licensed & 5.9 & 6.9 & -1.0 \\
\hline Fully licensed - initial & 16.7 & 10.6 & $6.1 * * *$ \\
\hline Fully licensed - continuing & 77.4 & 82.5 & $-5.1 * * *$ \\
\hline Turnover rate & 20.1 & 16.8 & $3.3^{* * *}$ \\
\hline 0 to 3 years of experience & 21.4 & 23.9 & -2.5 \\
\hline 4 to 10 years of experience & 18.6 & 15.7 & 2.9 \\
\hline 11 or more years of experience & 20.2 & 14.5 & $5.7 * * *$ \\
\hline
\end{tabular}

$* * * p<.001$ (two-tailed test).

Source. North Carolina Licensure-Salary Pay Snapshots data, 2010 and 2011; North Carolina Licensure-Salary License Area data, 2010; and North Carolina School Context data, 2010.

To help understand the quantitative data, we incorporated data from principal interviews. The data from these interviews suggest that early colleges may have a higher turnover rate due to the need to have a good fit between the teacher and the goals of the school. One early college principal stated:

...that's one thing my superintendent's always on to me about. He says my teacher retention is below the state average. Okay. I said, "Well, if I don't have a teacher that's going to be good or if I don't have a teacher that matches the rest of us, I want the teacher retention to be below state average." I don't want to keep the teacher who's not going to fit. I don't want to keep the teacher who's not going to be a good teacher. And I'm going to get rid of them, plain and simple, until we get a good match for everything. Right now I think we've got a good match. I really do. And I'm happy. And I'm hoping we don't have any teachers leave this year.

The interviews also highlighted a possible reason for the larger number of novice teachers in early colleges: the innovative environment of the early college can lead some principals to be more interested in hiring newer or younger teachers. One principal, for example, saw younger teachers as more aligned with the school's philosophy:

[Young teachers] come so ready. They understand the technology; they understand how education is changing. At the university now you are doing cooperative learning inside the classrooms now and all you have to do is just kind of feed them. They're ready to learn any and everything. It's not a paradigm shift.

For some principals, the fit with the school was more important than the level of teaching experience. Another early college principal reported that she asked a question during the hiring process about the importance of good relationships between the teacher and students. Although she would generally prefer not to hire first-year teachers, the answer to that question was more important than years of teaching experience:

...if you had less than one year of experience and you answered that question right, and you were up against somebody who had I don't care how many years of experience and they answered the question wrong...they were out of the mix, you were in the mix.

The goal to have a good fit between the early college's innovative environment and the teacher may be one reason for higher numbers of novice teachers and higher teacher turnover.

Another reason may be that the schools are relatively new. Early colleges are a relatively recent phenomenon in North Carolina, and some of these schools have only been open for a few years. As noted above, any new school faces challenges in recruiting staff and in establishing organizational capital and a shared sense of trust and mission (Berends et al., 2002; Desimione, 2002). Early colleges have different expectations of teachers and students than do traditional high schools. Teachers coming into a newly established early college may not fully understand these differences and may have difficulty adjusting to their new jobs. Over time, teachers may develop value consonance with the school, and the length of time the school has been open may influence teacher turnover and the percentage of novice teachers. 
To examine the relationship between years of operation and teacher qualifications, we used school-level data to graph turnover and the percentage of novice teachers by the number of years the early college had been open (Figure 1). These data show that the teacher turnover rate was highest in the first year of operation and declined over time. Specifically, the average teacher turnover rate for schools was $47 \%$ in the first year of operation and dropped to $9 \%$ in the seventh year of operation. Similarly, the percentage of novice teachers generally declined as the school became more established. For schools in their first year of operation, $29 \%$ of the teachers were novices, compared with $17 \%$ in the seventh year of operation. Over time, as the turnover rate declines, early colleges may not need to recruit new teachers, and the teachers who stay in school become more experienced.

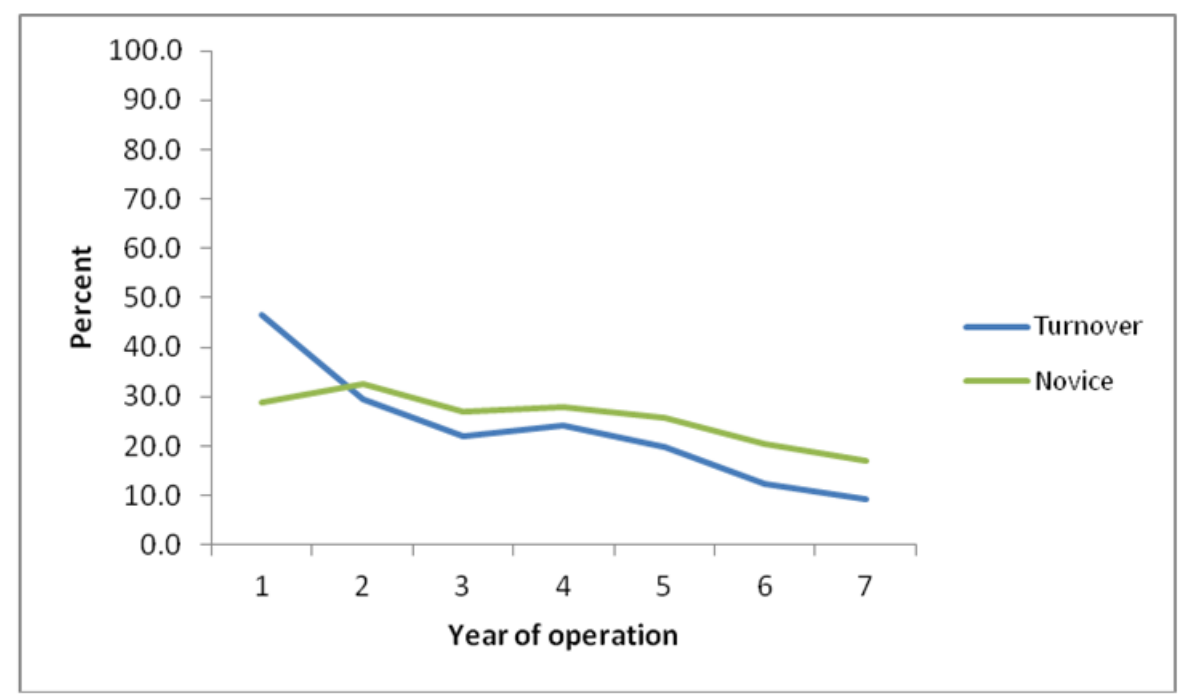

Figure 1. Teacher turnover and novice teacher averages for early college high schools in North Carolina, by year of operation

Source: North Carolina School Context data, 2006 through 2011.

\subsection{Leavers and Stayers}

Our initial analysis showed that early college teachers had higher teacher turnover, particularly in the first few years of a school's existence. To determine whether novice teachers in early colleges were more likely to leave, and whether the differences between leavers and stayers were greater in early colleges, we compared the characteristics of teachers who stayed in the same school between 2009-2010 and 2010-2011 to those of teachers who left. Table 2 compares leavers and stayers within early colleges and neighboring traditional schools. Of neighbor teachers in traditional high schools, more qualified teachers were more likely to leave. Leavers were more likely than stayers to be fully licensed. Of the neighbor teachers, those who were not fully licensed were more likely to stay than to leave ( $85 \%$ vs. $72 \%)$. However, a higher percentage of neighbor leavers were novices ( $24 \%$ of leavers vs. $15 \%$ of stayers), and a lower percentage of leavers had at least 11 years of experience ( $49 \%$ of leavers vs. $56 \%$ of stayers). Consistent with other studies of turnover, it seems that although traditional high schools faced challenges in retaining the most qualified teachers, they were able to keep more experienced teachers.

In contrast, early college leavers and stayers did not differ in terms of educational attainment or years of experience. Unlike novices in the traditional schools, early college novices were not more likely to leave. The only statistically significant difference between early college leavers and stayers was for those having a continuing license. Early college leavers were more likely to have a continuing license than stayers (11\% vs. $5 \%)$. Although the turnover rate in early colleges was higher, they did not lose either their most qualified or novice teachers at higher rates. 
Table 2. Qualifications of leavers and stayers for early college high school (ECHS) and traditional teachers in Early College districts.

\begin{tabular}{|c|c|c|c|c|c|c|c|}
\hline & \multicolumn{3}{|c|}{ ECHS teachers } & \multicolumn{4}{|c|}{ Traditional neighbor teachers } \\
\hline & $\begin{array}{l}\text { Leavers } \\
(\mathrm{N}=126)\end{array}$ & $\begin{array}{l}\text { Stayers } \\
(\mathrm{N}=500)\end{array}$ & & $\begin{array}{l}\text { Leavers } \\
(3,375)\end{array}$ & $\begin{array}{l}\text { Stayers } \\
(16,714)\end{array}$ & & $\begin{array}{l}\text { ECHS vs. Traditional } \\
\text { stayers }\end{array}$ \\
\hline & $\%$ & $\%$ & Difference & $\%$ & $\%$ & Difference & Difference \\
\hline \multicolumn{8}{|l|}{ Education } \\
\hline Bachelor's & 55.8 & 59.4 & -3.6 & 64.9 & 66.8 & $-1.9^{* *}$ & $-6.8^{* * *}$ \\
\hline Master's & 44.2 & 40.6 & 3.6 & 35.1 & 33.2 & $1.9^{* *}$ & $6.8^{* * *}$ \\
\hline \multicolumn{8}{|l|}{ Years of experience } \\
\hline 0 to 3 years (Novice) & 25.0 & 22.9 & 2.1 & 23.8 & 14.9 & $8.9 * * *$ & $8.2 * * *$ \\
\hline 4 to 10 years & 29.2 & 31.9 & -2.7 & 27.4 & 28.8 & -1.4 & 3.3 \\
\hline 11 or more years & 45.8 & 45.2 & 0.6 & 48.8 & 56.3 & $-7.5 * * *$ & $-11.5^{* * *}$ \\
\hline \multicolumn{8}{|l|}{ Licensed status } \\
\hline Not fully licensed & 73.4 & 78.4 & -5 & 72.3 & 84.6 & $-12.3 * * *$ & $-6.2 * * *$ \\
\hline Fully licensed - initial & 15.3 & 17.1 & -1.8 & 14.5 & 9.9 & $4.6^{* * *}$ & $7.6^{* * *}$ \\
\hline Fully licensed - continuing & 11.3 & 4.5 & $6.8 * * *$ & 13.3 & 5.6 & $7.7 * * *$ & -1.4 \\
\hline
\end{tabular}

Source. North Carolina Licensure-Salary Pay Snapshots data, 2010 and 2011; North Carolina Licensure-Salary License Area data, 2010; and North Carolina School Context data, 2010.

The final set of columns in Table 2 compares the qualifications of early college teachers who stayed in their jobs to those of the traditional teachers who stayed. Stayers in early colleges were more likely to have earned a master's degree than stayers in neighbor schools ( $41 \%$ vs. $33 \%)$. A smaller percentage of early college teachers who stayed were not fully licensed, compared with the traditional teachers (78\% vs. $85 \%)$. Thus, these early colleges had less difficulty retaining qualified teachers. Additionally, a higher percentage of early college stayers were novice teachers, compared with the stayers in the neighboring schools ( $23 \%$ vs. $15 \%)$. However, a smaller percentage of early college stayers had at least 11 years of experience, compared with neighboring teachers (45\% vs. 56\%). Unlike past research (cited above) showing that novice teachers were more likely than veteran teachers to exit, our analysis indicated that novice teachers in early colleges were not more likely to leave their jobs.

\subsection{Working Conditions in an Innovative School Setting}

Finally, we examined whether early college novice teachers were more satisfied than their peers in terms of perceptions of instructional support, shared leadership, and leaders' responsiveness to teacher concerns. Novice teachers responded to questions about the kinds of supports they received from their schools. (Survey responses for teachers with 4 to 10 years of experience and 11 or more years of experience mirror overall results and are available from the authors.)

Table 3 reports the types of supports that teachers received in their jobs. About $90 \%$ of all teachers had an orientation and an assigned mentor, and about $80 \%$ of all teachers reported having seminars. These results did not differ by school type (results available from authors). However, novice teachers in early colleges seemed to receive more personalized support in their jobs. A higher percentage of early college novice teachers reported having release time to observe teachers ( $72 \%$ vs. $41 \%)$, having formal time to meet with mentors $(70 \%$ vs. $55 \%)$, and having regular communication with administrators $(96 \%$ vs. $85 \%$ ). Early college novice teachers were more likely to strongly agree that the supports they received improved their instructional practices (38\% vs. $29 \%)$ and influenced their decision to continue teaching at the same school (36\% vs. $28 \%)$. 
Table 3. Percentage of early college high school (ECHS) and traditional novice teachers indicating that they received various types of support.

\begin{tabular}{|c|c|c|c|}
\hline & $\begin{array}{l}\text { ECHS } \\
\text { teacher } \\
(\mathrm{N}=114) \\
\%\end{array}$ & $\begin{array}{l}\text { Traditional novice } \\
\text { teacher } \\
(\mathrm{N}=7,557) \\
\%\end{array}$ & $\begin{array}{l}\text { ECHS novice teachers- } \\
\text { Traditional neighbor novice } \\
\text { teachers } \\
\text { Difference }\end{array}$ \\
\hline Release time to observe teachers & 71.9 & 40.8 & $31.1 * * *$ \\
\hline Formal time to meet with mentor & 70.2 & 55.0 & $15.2 * * *$ \\
\hline Regular communication w/administrator & 95.6 & 85.1 & $10.5^{* * *}$ \\
\hline $\begin{array}{l}\text { Additional support received as a new } \\
\text { teacher improved instructional practices }\end{array}$ & 37.7 & 29.2 & $8.5 * *$ \\
\hline $\begin{array}{l}\text { Additional support received as a new } \\
\text { teacher important in decision to continue } \\
\text { teaching at this school }\end{array}$ & 36.0 & 27.5 & $8.5^{* *}$ \\
\hline
\end{tabular}

$* * p<.05, * * * p<.01$ (two-tailed test).

Source. Teacher Working Conditions data, 2010.

Next, we examined teachers' overall perceptions of the school. As shown in Table 4, 60\% of early college novice teachers strongly agreed that "Overall, my school is a good place to work and learn," compared with $37 \%$ of traditional novice teachers. We then examined a set of questions about teachers' perceptions of leaders' responsiveness to various concerns: the use of time, professional development, community support/involvement, and managing student conduct. At least one third of early college novice teachers strongly agreed with each item. In contrast, less than $20 \%$ of neighbor novice teachers strongly agreed with any item. Among all novices, the leadership response to concerns about use of time had the lowest rating. However, early college novice teachers were still more satisfied that the leadership made a sustained effort to address this concern (33\% of early college novice teachers vs. $14 \%$ of neighbor novice teachers).

Table 4. Percentage of early college high school (ECHS) and traditional teachers in early college districts who strongly agreed that their school is a good place to learn and that leaders were responsive to teacher concerns.

\begin{tabular}{lccc}
\hline & $\begin{array}{l}\text { \% ECHS } \\
\text { teachers } \\
(\mathrm{N}=114)\end{array}$ & $\begin{array}{l}\text { \% Traditional } \\
\text { neighbor } \\
\text { teachers } \\
(\mathrm{N}=7,557)\end{array}$ & $\begin{array}{l}\text { ECHS teachers vs. Traditional } \\
\text { neighbor teachers } \\
\text { \% Difference }\end{array}$ \\
\hline $\begin{array}{l}\text { Overall, my school is a good place to } \\
\text { work and learn }\end{array}$ & 59.7 & 37.3 & $22.4^{* * *}$ \\
$\begin{array}{l}\text { The school leadership makes a sustained } \\
\text { effort to address teacher concerns about: }\end{array}$ & & & \\
$\quad$ & 33.3 & 13.5 & $19.8^{* * *}$ \\
The use of time in my school & 36.8 & 15.9 & $20.9^{* * *}$ \\
$\quad \begin{array}{l}\text { Professional development } \\
\text { Teacher leadership }\end{array}$ & 36.0 & 14.6 & $21.4^{* * *}$ \\
$\quad \begin{array}{l}\text { Community support and involvement } \\
\text { Managing student conduct }\end{array}$ & 36.8 & 15.5 & $21.3^{* * *}$ \\
\end{tabular}

$* * * p<.01$ (two-tailed test).

Source: Teacher Working Conditions data, 2010.

Finally, we examined questions pertaining to support for instruction and shared leadership. Table 5 presents the results for these items. Questions pertaining to support for instruction focused on having performance assessed objectively, receiving appropriate feedback on teaching, working in communities to develop and align instructional practices, and feeling encouraged to try new things to improve instruction. A greater percentage of early college novice teachers strongly agreed with each item than did neighbor novice teachers. Among early college novice teachers, $46 \%$ strongly agreed that their performance was assessed objectively and an equal percentage strongly agreed that they received feedback that could help them to improve their teaching. For neighbor novice teachers, fewer than 30\% strongly agreed with each of these items. Similarly, in terms of being encouraged to try new things to improve instruction, $61 \%$ of early college novice teachers strongly agreed, compared with $29 \%$ of neighbor novice teacher. However, $33 \%$ of the early college novice teachers strongly agreed that teachers work in professional learning communities to develop and align 
instructional practices, compared with $25 \%$ of neighbor novice teachers. Here, the difference between the early college novice teachers and their traditional peers was not statistically significant.

Questions about shared leadership include agreement with whether faculty and leadership have a shared vision, there is an atmosphere of trust and mutual respect, teachers feel comfortable raising issues and concerns, and teachers are effective leaders at this school. About twice as many early college novice teachers strongly agreed with each of these items compared with their neighbor novice teachers. For example, $45 \%$ of early college novice teachers strongly agreed that the school had a shared vision, compared with $19 \%$ of the neighbor novice teachers.

Table 5. Percentage of early college high school (ECHS) and traditional teachers in early college districts who strongly agreed with items associated with shared leadership.

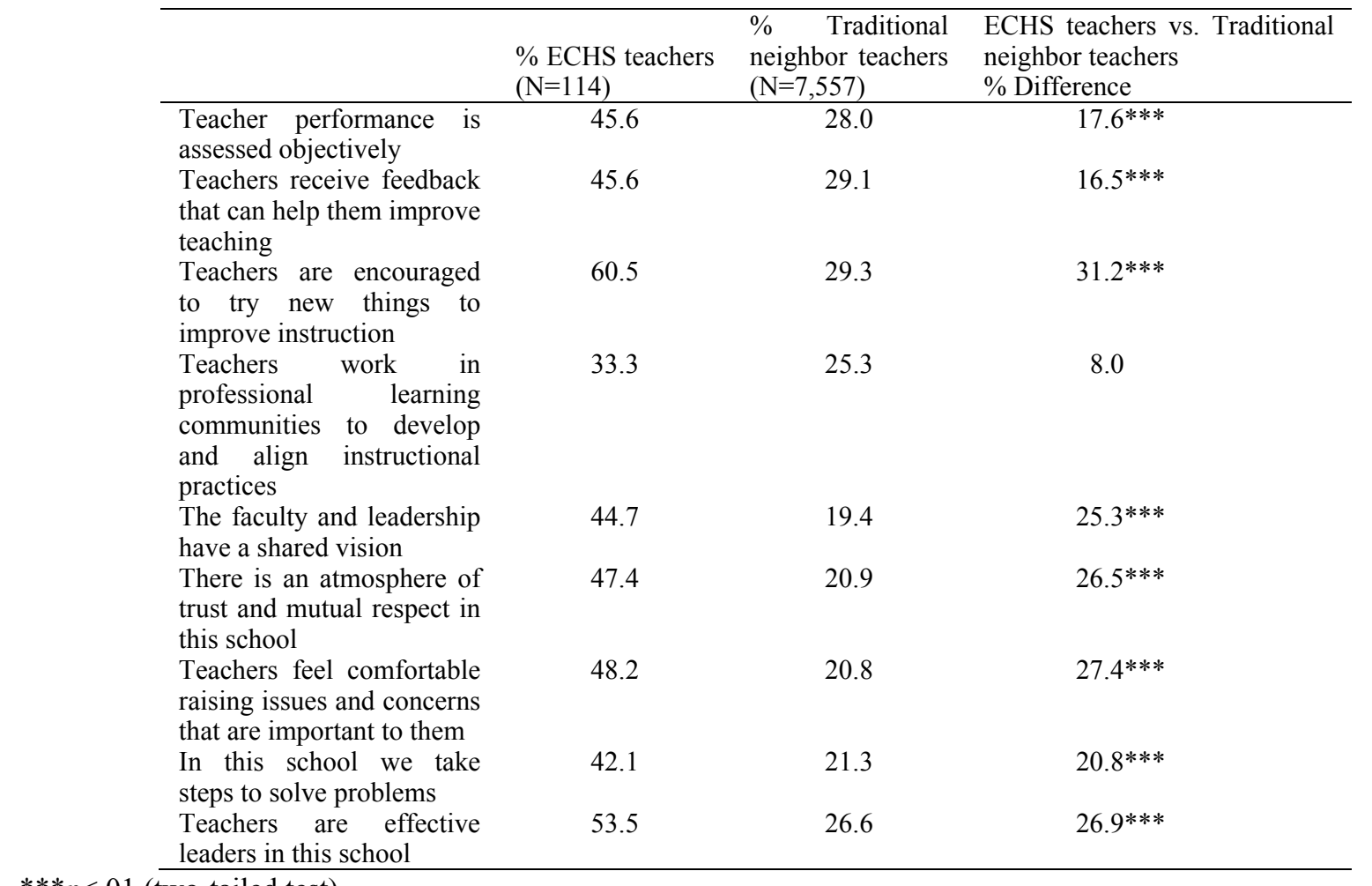

$* * * p<.01$ (two-tailed test).

Source: Teacher Working Conditions data, 2010.

\section{Discussion}

In the United States, some schools face challenges in retaining qualified teachers, and much research shows that novice teachers are more likely to leave their jobs than veteran teachers. Teacher turnover is disruptive to all schools, but new schools and those undergoing comprehensive reform have additional challenges of creating organizational capital and fostering a shared sense of mission. In North Carolina, early colleges are directed to emphasize design principles that focus on the culture of teaching and learning. This article examined whether the schools in this reform model are better able to retain qualified teachers than traditional schools in their districts and whether early college novice teachers are more satisfied than their traditional peers with their working conditions. Using longitudinal employment data for every high school teacher in an early college district and survey data from teachers in these schools, we examined qualifications of teachers, characteristics of teachers who leave jobs, and novice teachers' perceptions of the supports they receive and their work environment.

Early college and neighbor teachers did not differ in the percentage who were not licensed, while a higher percentage of early college teachers had graduate degrees than neighbor teachers. However, a higher percentage of early college teachers were novices compared with their traditional peers, and turnover rates were higher in early colleges. Nevertheless, early college novice teachers were not more likely to leave their jobs than neighbor novice teachers. In traditional schools, both novice teachers and more qualified teachers (e.g., fully licensed, master's degree) were more likely than veteran or less experienced teachers to leave. In contrast, even though their overall turnover rate was higher, early colleges did not lose a disproportionate number of their most qualified teachers or novice teachers. Given that these were relatively newly established schools with a higher turnover rate, it is not surprising that a higher percentage 
of early college teachers were novices. As these novice teachers were less likely to leave, it seems that these schools will reap the benefits of investing in them. In planning for comprehensive school reform, policymakers should account for the fact that teacher turnover may be higher as the program first gets underway.

Interviews indicate that early college principals believe that teachers have to fit with the school culture. Having teachers who fit the model is more important than reducing turnover by holding on to teachers who do not fit. Some principals seem to believe that novice teachers may be more flexible in adapting to the challenges of this model. All newly established schools and those undergoing comprehensive reform need time to find teachers who will support their mission and to develop organizational capital through a shared understanding of the mission and relational trust. We found that schools that had been in existence longer had lower turnover rates and lower percentages of novice teachers than newly created schools. In time, innovative reform models may become better able to retain qualified teachers than traditional schools. Future evaluation of school reforms should account for the length of time it may take for a reform to be fully implemented, although it can be challenging and expensive to track the process of a new reform model over years. Results from early years should be interpreted cautiously.

Finally, we analyzed the results for novice teachers who participated in the Teacher Working Conditions Survey. One of the design principles of North Carolina's early colleges is personalization of educational resources, and early college novice teachers received more personalized support through having formal times to communicate with mentors and regular communication with administrators. In contrast, novice teachers in traditional high schools were more likely to participate in less personal seminars.

About $20 \%$ more early college novice teachers strongly agreed with the statement, "Overall, my school is a good place to work and learn" than their traditional peers did, and a higher percentage of them agreed that the supports they received influenced their instruction and decisions to remain at that school. A higher percentage of early college novice teachers strongly agreed that leadership made a sustained effort to address various teacher concerns. Early college novice teachers also strongly agreed with statements indicating that they perceived support for instruction and a shared sense of leadership, compared with neighbor teachers. Traditional schools facing challenges in retaining teachers could foster a supportive culture to help teachers feel that leaders are responsive to their concerns.

The only area in which there was no difference between early college novice teachers and their traditional peers was in strongly agreeing with the statement, "Teachers work in professional learning communities to develop and align instructional practices." It may take time for new teachers to feel part of a professional learning community, whether or not they teach in an early college. With these consistently positive responses to questions about leadership roles, it is striking that early colleges have higher turnover rates than their neighboring schools. As turnover rates are highest when schools initially open, it seems that it takes time to find teachers whose abilities and temperaments match a new reform model.

This study has some limitations. First, we cannot link the survey results to the licensure-salary data. Given that the state calculates turnover rates based on departures from one March to the next and the Working Conditions Survey was administered in the spring, some school leavers may not have taken this survey. We cannot tell whether those who left their jobs responded to the survey at all or whether they felt dissatisfied with particular aspects of their jobs. Second, because the Teacher Working Conditions Survey data do not identify respondents, records from one administration to the next cannot be linked and we cannot tell whether a person becomes more or less satisfied over time or whether someone who changes jobs becomes more satisfied. However, by conducting multiple surveys of teachers over time and linking the results, one could examine whether teachers' perceptions change as they gain experience, how their perceptions change if they change schools, and what differences between the schools influence the change in perceptions.

Data-linking obstacles aside, early colleges are an innovative model and, just as expectations for students are higher, so are expectations for teachers. Some teachers may have difficulty adjusting, and some principals think that teacher turnover is less of a problem than retaining teachers who do not adopt the model. We noted that turnover rates are lower in early colleges that have been open longer, probably because these schools have had more time to attract teachers who embrace the model and develop organizational capital. Future research on school reform could incorporate the length of time since a program's inception.

Much research finds that novice teachers are more likely to leave their jobs than veteran teachers are. Yet, early college novice teachers are not. Their perceptions of leadership support and a sense of shared leadership may help build their commitment to these schools. In North Carolina, early colleges are organized around a publicized set of design principles, and that clarity makes it easier for these goals to become part of new teachers' teaching norms. Yet, the turnover rate for early college veteran teachers is higher than in traditional schools. It may be more difficult for those 
with more than 10 years of experience to change their practices to adapt to these new teaching styles. Consequently, they might benefit from more professional development and coaching as they make this transition.

The early colleges can serve as a case study of how innovative schools can both exacerbate and mitigate teacher turnover. As a school becomes more mature, teacher turnover decreases among the teaching force. Innovative schools can foster a shared sense of leadership with a shared vision. They can help teachers, particularly novices, feel a part of the community. Here, novice teachers have more positive perceptions of leadership support than their peers in traditional schools. Under certain supportive conditions, novice teachers do not leave a school at higher rates than more experienced teachers.

\section{Acknowledgement}

This material is based on work supported by the Institute of Education Sciences under grant \#R305A110085 and grant \#R305A140361. Data from the North Carolina Department of Public Instruction were made available through the North Carolina Education Research Center at Duke University. Authors are grateful for that support and the assistance of Annaliza Nunnery, Barbara Elliott, and Jon Paslov.

\section{References}

Allen, M. (2005). Eight questions on teacher recruitment and retention: What does the research say? http://www.ecs.org/html/educationissues/teachingquality/trrreport/home/TeacherRecruitmentRetention.pdf.

Allensworth, E., Ponisciak, S., \& Mazzeo, C. (2009). The schools teachers leave: Teacher mobility in Chicago public schools. Chicago, IL: Consortium on Chicago School Research.

American Association of State Colleges and Universities. (2005). The facts-and fictions-about teacher shortages. Policy Matters, 2(5).

Barnes, G., Crowe, E., \& Schaeffer, B. (2007). The cost of teacher turnover in five school districts: A pilot study. Washington, DC: National Commission on Teaching and America's Future.

Bellera, C. A., Julien, M., \& Hanley, J. (2010). Normal approximations to the distributions of the Wilcoxon statistics: Accurate to what N? Graphical insights. Journal of Statistics Education [Online], 18(2). www.amstat.org/publications/jse/v18n2/bellera.pdf

Berends, M. (2000). Teacher reported effects of New American Schools design: Exploring relationships to teacher background and school context. Education Evaluation and Policy Analysis, 22(1), 65-82. http://dx.doi.org/10.3102/01623737022001065

Berends, M., Bodilly, S., \& Kirby, S. N. (2002). Facing the challenges of whole school reform. Santa Monica, CA: RAND.

Berger, A., Turk-Bicakci, L., Garet, M., Song, M., Knudsen, J., Haxton, C., Zeiser, K., Hoshen, G., Ford, J., Stephen, J., Keating, K., \& Cassidy, L. (2013). Early college early success: Early college high school initiative impact study. http://www.air.org/focus-area/education/index.cfm? fa=viewContent\&content_id=2640\&id=1

Boyd, D. J., Grossmam, P. L., Ing, M., Lankford, H., Loeb, S., \& Wycoff, J. H. (2011). The influence of school administrators on teacher retention decisions. American Educational Research Journal, 48(2), 303-333. http://dx.doi.org/10.3102/0002831210380788

Creswell, J. W., \& Plano Clark, V. L. (2011). Designing and conducting mixed methods research (2nd ed.). Thousand Oaks, CA: Sage.

Creswell, J. W., Plano Clark, V. L., Gutmann, M. L., \& Hanson, W. E. (2003). Advanced mixed methods research designs. In A. Tashakkori \& C. Teddlie (Eds.), Handbook of mixed methods in social and behavioral research (pp. 209-240). Thousand Oaks, CA: SAGE Publications.

Cullen, J. B., Levitt, S. D., Robertson, E., \& Sadoff, S. (2013). What can be done to improve struggling high schools? Journal of Economic Perspectives, 27(2), 133-152. http://dx.doi.org/10.1257/jep.27.2.133

Curtis, C. (2012). Why do they choose to teach - and why do they leave? A study of middle school and high school mathematics teachers. Education, 132(4), 778-789.

Desimione, L. (2002). How can comprehensive school reform models be successfully implemented? Review of Educational Research, 72(3), 433-479. http://dx.doi.org/10.3102/00346543072003433

Edmunds, J. A., \& McColskey, W. (2007). Levers for change: Southeast Region state initiatives to improve high schools. (Issues \& Answers Report, REL 2007-No. 024). Washington, DC: U.S. Department of Education, Institute of Education Sciences, National Center for Education Evaluation and Regional Assistance, Regional Educational Laboratory Southeast. 
Edmunds, J., Bernstein, L., Glennie, E., Wilse, J, Arshavsky, N., Unlu, F., \& Dallas,A. (2010). Preparing students for college: the implementation of the early college high school model. Peabody Journal of Education. 85(3) 348-64.

Gray, L., \& Taie, S. (2015). Public school teacher attrition and mobility in the first five years: Results from the first through fifth waves of the 2007-08 Beginning Teacher Longitudinal Study (NCES 2015-337). U.S. Department of Education. Washington, DC: National Center for Education Statistics. http://nces.ed.gov/pubsearch

Hanushek, E. A., Peterson, P. E., \& Woessmann, L. (2013). Endangering prosperity: A global view of the American school. Washington, DC. Brookings Institution Press.

Harris, W. D. (2015). Changing the Lens: Mentors and their effect on novice teacher attitudes toward student achievement. Northridge, CA: California State University. Doctoral thesis.

Holme, J. J., \& Rangel, V. S. (2012). Putting school reform in its place: Social geography, organizational social capital, and school performance. American Educational Research Journal, 49(2), 257-283. http://dx.doi.org/10.3102/0002831211423316

Ingersoll, R. M. (2012). Beginning teacher induction: What the data tell us" Phi Delta Kappan, 93(8), 47-51. http://dx.doi.org/10.1177/003172171209300811

Ingersoll, R. M., \& May, H. (2012). The magnitude, destinations, and determinants of mathematics and science teacher turnover. Educational Evaluation and Policy Analysis, 34(4), 435-464. http://dx.doi.org/10.3102/0162373712454326

Ingersoll, R. M., \& Smith. (2004). Do teacher induction and mentoring matter? NASSP Bulletin, 88, 28-40. http://dx.doi.org/10.1177/019263650408863803

Jo, S. H. (2014). Teacher commitment: Exploring associations with relationships and emotions. Teaching and Teacher Education, 43, 120-30. http://dx.doi.org/10.1016/j.tate.2014.07.004

Johnson, R. B., Onwuegbuzie, A. J., \& Turner, L. A. (2007). Toward a definition of mixed methods research. Journal of Mixed Methods Research, 1(2), 112-133. http://dx.doi.org/10.1177/1558689806298224

Johnson, S. M., Kraft, M. A., \& Papay, J. P. (2012). How context matters in high-need schools: The effects of teachers' working conditions on their professional satisfaction and their students' achievement. Teachers College Record, 114(10), 1-39.

Kahne, J. E., Sporte, S., de la Torre, M., \& Easton, J. Q. (2006). Small schools on a larger scale: The first three years of the Chicago high school redesign initiative. Chicago: Consortium on Chicago School Research.

Kaniuka, T., \& Vickers, M. (2010). Lessons learned: How early college high schools offer a pathway for high school reform. NASSP Bulletin, 94, 165. http://dx.doi.org/10.1177/0192636510384982

Keigher, A. (2010). Teacher attrition and mobility: Results from the 2008-09 Teacher Follow-up Survey (NCES 2010-353). http://nces.ed.gov/pubs2010/2010353.pdf

Ladd, H. F. (2011). Teachers' perceptions of their working conditions: How predictive of planned and actual teacher movement? Educational Evaluation and Policy Analysis, 33(2), 235-261. http://dx.doi.org/10.3102/0162373711398128

Liu, X. (2007). The effect of teacher influence at school on first-year teacher attrition: A multilevel analysis of the Schools and Staffing Survey for 1999-2000. Educational Research and Evaluation, 13(1), 1-16. http://dx.doi.org/10.1080/13803610600797615

Nahapiet, J., \& Ghoshal, S. (1998). Social capital, intellectual capital, and the organizational advantage. Academy of Management Review, 32(2), 242-266.

Newton, X. A., Rivero, R., Fuller, B., \& Dauter, L. (2011). Teacher stability and turnover in Los Angeles: The influence of teacher and school characteristics. http://edpolicyinca.org/sites/default/files/2011_PACE_WP_NEWTON.pdf

North Carolina Department of Public Instruction. (2010). NC school report cards: Data sources and information. http://www.ncreportcards.org/src/

North Carolina New Schools. (2013). Design principles: Proven approach for educational innovation. http://ncnewschools.org/uploads/resources/resource-design-principles.pdf

North Carolina Professional Teaching Standards Commission. (2010). North Carolina's teacher working conditions initiative. http://www.ncteachingconditions.org/index

Pogodzinski, B., Youngs, P., \& Frank, K. A. (2013). Collegial climate and novice teachers' intent to remain teaching. American Journal of Education, 120(1), 27-54. http://dx.doi.org/10.1086/673123 
Ronfeldt, M., Loeb, S., \& Wyckoff, J. (2013). How teacher turnover harms student achievement. American Educational Research Journal, 50(1), 4-36. http://dx.doi.org/10.3102/0002831212463813

Skaalvik, E. M. \& Skaalvik, S. (2011). Teacher job satisfaction and motivation to leave the teaching profession: Relations with school context, feeling of belonging, and emotional exhaustion. Teaching and Teacher Education. 27(6), 1029-38. http://dx.doi.org/10.1016/j.tate.2011.04.001

Simon, N. S. \& Johnson, S. M. (2015). Teacher Turnover in High-Poverty Schools: What We Know and Can Do. Teachers College Record. 117(3), 1-36.

Smith, T. M., \& Ingersoll, R. M. (2004). What are the effects of induction and mentoring on beginning teacher turnover? American Educational Research Journal, 41(3), 681-714. http://dx.doi.org/10.3102/00028312041003681

\section{$(\mathrm{Cc}) \mathrm{EY}$}

This work is licensed under a Creative Commons Attribution 3.0 License. 